\title{
FORASTEIROS NA PÁTRIA-MÃE: O LUGAR DO MIGRANTE EM THE LONELY LONDONERS, DE SAMUEL SELVON E THE FINAL PASSAGE, DE CARYL PHILLIPS
}

Denise Almeida Silva

Universidade Regional do Alto Uruguai das Missões

\section{Resumo}

Este estudo analisa a construção ficcional da identidade do migrante em The Lonely Londoners (1956), de Samuel Selvon e The Final Passage (1985), de Caryl Phillips. Ambos os romances enfocam a experiência da geração Windrush, recrutada das colônias para suprir mão de obra na Inglaterra do pós-guerra. Ressalta-se o espaço intersticial ocupado pelas comunidades migrantes, e estuda-se a construção da identidade nessas obras dentro do contexto das relações culturais, analisando-se as políticas de afiliação, pertencimento e exclusão implícitas na formação dessas comunidades diaspóricas.

Palavras-chave: diáspora, migrantes, geração Windrush.

Por sua natureza, a comunidade ocupa posição essencialmente ambígua: como parte do todo experimenta com ele uma dupla relação de pertinência e alteridade, ocupando um espaço de contingência e indeterminação. Torna-se impossível o estabelecimento de uma linha

\begin{tabular}{|l|l|l|l|l|}
\hline Ilha do Desterro & Florianópolis & $n^{\circ} 54$ & p. 039- 059 & jan./jun. 2008 \\
\hline
\end{tabular}


objetiva de separação - a comunidade é uma forma de agência que "vaza pelos interstícios da estrutura objetivamente construída e contratualmente regulada da sociedade civil" (Bhabha,1998, p. 316). Assim, ocupa um lugar liminar no qual a diferença é construída, não de forma singular ou binária, mas a partir de um entre-lugar em que se constroem formas de identidade social que "devem ser capazes de surgir dentro-e-como diferença de um-outro" (id, p. 322). Através deste processo de hibridação forma-se um "terceiro espaço" que não pode ser confundido com os espaços originais e que, deslocando as histórias que o constituem, gera nova estrutura (Bhabha, entrevista a Rutherford, 1995, 36-37).

Dado o caráter iminentemente hibrido da comunidade, falar em comunidades diaspóricas é de certa forma uma tautologia quando se define diáspora, como o faz Stuart Hall, "não pela essência ou pureza, mas pelo reconhecimento de uma necessária heterogeneidade e diversidade, por uma concepção de 'identidade' que se constrói com e através, e não apesar, da diferença, pela hibridação" (Hall, 1990, p. 119120). Identidade, ou aquilo que somos, poderia com mais precisão ser definido como aquilo que nos tornamos: a identidade cultural não se forma no vácuo, nem é algo que transcende lugar, tempo, história ou cultura, mas um processo histórico, e como tal em constante transformação (id, p. 112).

Uma vez que o processo de negociação identitária necessariamente pressupõe certa ancoragem no passado, a questão da identidade migrante, especialmente no contexto pós-colonial, apresenta algumas particularidades interessantes. Como nos lembra Bhabha, o encontro do Ocidente com seus outros através de suas relações e possessões coloniais ocorre no momento em que nascem a modernidade e a democracia. Incapaz de conciliar democracia e solidariedade com domínio e conquista, o Ocidente deixa de escrever sua história como poder colonial despótico. Essa história silenciada, porem, é reinscrita pelos povos pós-coloniais, cujo retorno à metrópole muda suas ideologias culturais e tradições intelectuais através de questionamento 
da autenticidade e autoridade das grandes narrativas metropolitanas de progresso, lei e ordem. Além de sugerir que essas narrativas não podem ser concebidas sem que se invoque a face oculta da missão civilizatória, a revisão efetuada pelos excêntricos sugere também que "a linguagem dos direitos e deveres [...] deve ser questionada com base na situação legal e cultural discriminatória e anômala a que estão submetidos os migrantes [...] que se encontram do outro lado da lei" (entrevista a Rutherford, 1996, p. 40).

A diferença entre a pátria imaginada e a maneira como esta se apresenta na realidade é um motivo comum na literatura de migração. Tendo herdado a língua, modelo educacional e estrutura administrativa da pátria-mãe, o migrante chega à metrópole presumindo conhecê-la tão bem quanto os cidadãos lá nascidos, uma presunção que se desfaz frente à realidade que passa a conhecer. Submetidos a um processo de estranhamento, já os parágrafos iniciais de The Lonely Londoners põem em relevo o choque entre a Inglaterra como a comunidade imaginada pelos recém-chegados e a Inglaterra real que está para ser vivenciada por eles. Como percebida por Moses Aloetta ao se dirigir para a estação de Waterloo, a cidade parece estar envolta num manto de irrealidade. Contudo, a neblina e as luzes que brilham indistintamente através dela ao entardecer, indicadores que fazem com que Londres pareça "algum estranho lugar de outro planeta"1 (Selvon, 1991, p. 7), são traços típicos do cenário londrino.

Percebida como um "um lugar onde você vê pessoas chorando despedidas e beijando boas vindas", a estação de Waterloo intensifica a sensação de deslocamento de Moses, que experimenta então "saudades de casa nunca antes experimentadas em nove-dez anos no país" (p. 9). De certa forma, o intenso movimento de ida e vinda prenuncia o desarraigamento e mobilidade de seres como Bart e Captain, de quem se diz vaguear por Londres "movendo-se de um lugar para o outro, semana após semana" (p. 48), "fazendo nada, tendo nada (...) fumando Benson e Hedges quando as coisas vão bem, se contentando sem fumar quando vão mal" (p. 44). 
Por outro lado, a ambiência de Waterloo introduz a importância da comunidade na vida do migrante, uma vez que propicia o estreitamento de elos familiares (como quando a família de Tolroy chega à Inglaterra) e a acolhida a velhos conhecidos ou mesmo completos estranhos (como tipificado pelo encontro em Moses e Sir Galahad). Experiente e bem articulado, Moses é o exemplo mias bem delineado de uma rede de ajuda mútua entre a comunidade diaspórica, que ultrapassa os limites do solo britânico, alcançando o Caribe. Migrantes que, como Jackson, retornam à pátria de origem, fornecem nomes e endereços de pessoas que podem prestar ajuda na localização de moradia e de emprego; uma vez em Londres, os recém-chegados são distribuídos pela cidade por residentes como Samson, empregado no setor de bagagens de King's Cross, ou como o próprio Moses. A casa deste último é utilizada tanto como hotel para os desabrigados, motel para os encontros ocasionais dos compatriotas sem teto e ponto de encontro em que a comunidade se reúne para comer e conversar. Esse trânsito acaba fornecendo o próprio motivo estruturador do romance, que é o somatório do relato das experiências de cerca de uma dúzia de personagens cujas vidas se cruzam com a de Moses Aloetta.

Em contraste com o romance de Selvon, em que a identidade migrante é construída a partir da sobreposição de historias individuais, The Final Passage destaca um casal, Michel e Leila, uma escolha que propicia a exploração das motivações, aspirações, ajustes e desajustes dessa população tanto a partir da ótica masculina como da feminina. A história de Leila é traçada a partir de uma linha matrilinear que enfatiza o valor de comunidades femininas como fonte de auxilio e apoio mútuos, tema bastante tradicional no romance das Anilhas e no romance negro. Já os valores que norteiam a vida de Michel originamse em visão patriarcal na qual o homem, provedor da casa, reserva-se o direito de não compartir decisões com a mulher, e de não lhe dever estrita fidelidade.

Estar na Inglaterra é para Michael e Leila uma questão de escolha. Ambos decidem $m$ abandonar sua terra natal movidos pelo desejo do sucesso, definido não tanto como bom êxito, mas como a impossibilidade 
de falhar. Este se torna um valor norteador para eles, como patenteado pela constante repetição de frases como a exortação da avó de Michael, "Não quero que você falhe" (Selvon, 1985, p. 110).

Sucesso tem significado diferente para cada um dos cônjuges. Para Michael é importante o sucesso material; para Leila, sucesso está mais ligado à habilidade e possibilidade de estabelecer relacionamentos significativos. A diferença de perspectiva baseia-se não apenas numa característica de gênero, mas na experiência vital de cada um. Percebendo-se mal amada pela mãe, com quem não consegue estabelecer comunicação efetiva, física e psiquicamente desvalorizada por namorado anterior e repetidamente abandonada e abusada pelo marido, Leila sente intenso desejo de ser amada e valorizada como mulher e como filha. Sucesso - ou não falhar - significa para ela encontrar a mãe na Inglaterra e finalmente romper a barreira do silencio, de forma a comungar com ela não tanto o solo inglês, mas pensamentos e sentimentos. Não falhar significa ainda para ela mostrar à mãe que ainda está casada, e tornar o casamento, ao qual aquela se opusera, uma comunhão de corpos e mentes, partilhado e não apenas tolerado.

A diferença no padrão de valoração de Leila e Michael reflete-se ainda na importância atribuída à comunidade por cada um deles. Leila, privilegiando valores relacionais, encontra na amizade feminina o apoio que lhe permite enfrentar as frustrações do casamento. Em St. Patrické a amizade de Millie que a conforta e a auxilia quando mais necessita, provendo-lhe companhia e pressionando Michael a reavaliar o tratamento que lhe dispensa; em Londres conta com a amizade de Mary. É essa vizinha branca que a leva a lugares de outra forma inacessíveis a ela; juntas compram roupas, tomam chá, conversam e riem. É Mary quem empresta dinheiro a Leila para que compre agasalho para Calvin; é ela quem cuida da criança enquanto Leila trabalha, quem se preocupa com a saúde da amiga quando Michael a abandona e quem se faz presente, com toda a família, no enterro de sua mãe. Já Michael busca as amizades que o ajudarão a realizar seu sonho de sucesso. Embora tão decepcionado com o lugar que lhe serve de moradia quanto Leila, subempregado e discriminado no emprego, não se permite replicar a 
experiência daqueles que "vêm com nada de casa para ser ainda maiores nadas" na Inglaterra (p. 167-168). Não contente com o emprego monótono e sem perspectivas, desiste do trabalho e decide formar sociedade com Edwin, muito embora tenha de admitir a Leila que desconhece que tipo de empreendimento iniciará. Não lhe interessa tanto o presente como o futuro. Em contraste com Leila, Michael afasta o compromisso familiar de sua mente, uma vez que este lhe parece carga que dificulta sua concentração no ideal do sucesso. Procura, antes, a companhia daqueles que lhe ajudarão a construir um espaço na nova pátria: busca os compatriotas, indo ao recém aberto Clube Caribenho.

Caryl Phillips ressalta a forte propensão associativa dessa população para com a Inglaterra. Mesmo antes que o navio SS Winston Churchill se afastasse do porto, Leila já considera a terra natal como "o país que tinha sido o seu lar" (p. 20, grifo acrescentado). Sendo todos "da mesma bandeira, do mesmo império", os migrantes imaginam que devem chegar "meio-ingleses" (p. 142). Esse gesto afiliativo, baseado em uma meio cidadania, contudo, denuncia a fragilidade da construção dessa identidade inglesa. Outros gestos aflitivos são o cultivo da moda (ou o que pensam ser moda) na Inglaterra, como quando Michael considera a conveniência de deixar crescer bigode para a viagem, ou tentativas de imersão na cultura inglesa, especialmente através da leitura, com destaque para a Enciclopédia Britânica. No convés do navio os viajantes concordam que a história da Inglaterra de Churchill é um clássico, mas ignoram-lhe o nome2; gabam-se de saber "tudo", "e mais" e "muito mais" sobre a Inglaterra, mas ignoram quem ocupa o trono inglês, necessitando que um compatriota que fora aluno externo da Universidade de Londres lhes explique que uma rainha, e não um rei, é o atual monarca (Selvon, 1985, p. 140-142). Esse conhecimento presumido, construído a partir de histórias ouvidas, reminiscências e leituras parcialmente compreendidas acaba por produzir uma imagem tão pálida e distorcida do país a que se dirigem que se torna quase sinônimo de total desconhecimento. Ignorância da geografia britânica e do registro lingüístico apropriado são evidenciados, ainda, através dos "endereços esperançosos" garatujados em maiúsculas na bagagem, como: 


\begin{abstract}
'ALPHONSO EDWARDES, SLOUCH, PERTO DE BUCKS, INGLATERRA, GRÃ-BRETANHA'. (...) 'PROPRIEDADE DE LARRINGTON SEVILLE. A SER MANUSEADO COM CUIDADO. DESTINADO À FACULDADE DE DIREITO DE LONDON COLLEGE. INGLATERRA. MUITO OBRIGADO (p. 10-11).
\end{abstract}

O fato de que Winston Churchill é por duas vezes mencionado em associação aos migrantes não parece ser mera coincidência. O primeiro ministro inglês à época da Segunda Guerra Mundial, sem dúvida um dos mais importantes líderes da moderna Grã-Bretanha, aderiu firmemente à história Whig, abraçando a crença dos séculos XVIII e XIX de que a Inglaterra estava destinada à grandeza imperial, e de que toda a história britânica deveria se mover para alcançar o cumprimento deste destino. Se o Império lhe era particularmente caro, o era como instrumento para garantir a grandeza e defesa da Inglaterra ${ }^{3}$; repetida e abertamente condenou a independência da Índia. Assim, a menção do nome de Churchill, que mesmo na política doméstica se opôs a idéias populares, como a melhoria da saúde e educação públicas, sutilmente sugere que a esperança de dias melhores desses coloniais dificilmente viria a se tornar realidade. A descrição dos espaços que ocupam no navio (como o convés, que mais parece uma rua de favela, com roupas penduradas secando ao sol), ou a repetida descrição das bagagens (malas já muito gastas, a mala única que contém todos os pertencentes de uma família, ou ainda as caixas de papelão usadas como mala) contribuem para reforçar a impressão de que a pretendida riqueza na pátria-mãe não passa de um sonho desses homens e mulheres, alinhados no convés como se fossem o "elenco de uma ópera trágica" (Phillps, p. 139).

A cena do desembarque acentua diferenças, sendo a primeira e mais visível das quais a diferença racial, mútua e imediatamente percebida tanto pelos antilhanos como pelos ingleses. A observação "Nunca vi tanta gente branca na minha vida" é contrabalançada pela compreensão de que o mar de faces brancas que os fita provavelmente "nunca viu tanta gente de cor também" (p. 142). Essa primeira visão 
provoca em Leila uma sensação de vazio. Antes mesmo de registrar completamente o que é apreendido pela visão, percebe seu deslocamento, e intui que teria que construir uma nova identidade cultural. Descreve o novo país a partir das qualidades que deixa de possuir quando comparado à terra de origem:

Não havia montanhas verdes, não havia mulheres coloridas com cestas na cabeça vendendo amendoins ou bananas ou mangas, não havia árvores, nenhuma casa branca nas colinhas, nenhuma colina, nenhuma casa de madeira à beira mar, e o mar não era azul e não havia praia, e não havia nuvens, só um grande nuvem, e eles tinham chegado (p. 142).

Segue-se o desfile perante as câmaras de TV, cujas lentes registram tanto a diversidade cultural dos recém-chegados como sua pobreza, como evidenciada pelos lenços que envolvem as cabeças das mulheres e as anáguas rosa choque aparecendo por baixo dos seus vestidos curtos, ou os coloridos suéteres sem manga e os shorts brancos com bolsos enormes com que os homens se vestiam.

A cobertura televisiva, brevemente enfocada por Phillips, é tematizada em The Lonely Londoners, em que se ressalta o papel a imprensa no fomento do preconceito racial. A defesa os valores hegemônicos por parte da mídia branca é inicialmente exemplificada no episódio do jornalista que cobre a chegada da nova leva de viajantes vindos do Caribe. Interessa a ele investigar a situação na colônia e o motivo por que tantos se deslocam para a Inglaterra. Moses Aloetta astutamente evade a primeira pergunta, escolhendo antes comentar sobre furacão recentemente ocorrido na Jamaica; por outro lado, aproveita a segunda pergunta para rapidamente passar do comentário sobre a falta de trabalho na terra de origem para a penúria do colonial na Inglaterra. É evidentemente interrompido pelo jornalista, que encontra na tia de Tolroy uma interlocutora ingênua que não apenas lhe dá as respostas esperadas ("dizem que tem mais trabalho na Inglaterra, e salário melhor") como ajunta toda a família para a foto que 
aparece estampada no jornal no dia seguinte, acompanhada da manchete "Agora Família Jamaicanas Vem à Inglaterra". Recém chegada, a tia de Tolroy não entende que a "boa pergunta do cavalheiro" destina-se a obter do próprio migrante evidência testemunhal da chegada em massa de coloniais negros, alimentado assim os temores e preconceitos da população branca.

O papel e modo de atuação da mídia em seu conflito de interesses com a comunidade migrante negra são contrastados com o modo como opera a circulação de informações na estação de Waterloo: oportunizando o encontro de recém chegados com conterrâneos já radicados no país, esse local assume o papel de um jornal, proporcionando à diáspora caribenha na Inglaterra contato e primeira mão com fatos acontecidos em seus países de origem, como neste típico diálogo:

Oi Watson! O que você 'tá fazendo aqui na Inglaterra, cara? 'Por que não me escreveu que tava vindo?' E eles começavam uma conversa longa sobre os velhos tempos com os viajantes, descobrindo o que acontecia em Trindade, em Granada, em Barbados, na Jamaica e em Antigua, qual era o calipso da moda, quem tinha morrido, e assim por diante, e perguntando para desconhecidos coisas que eles não sabiam, como se conheciam a tia Simmons que mora em Labasse em Port of Spain, ou um cara chamado Harrington que trabalha na Red House. (Selvon, p.10)

Como descrita na colorida linguagem do narrador do romance de Selvon, trata-se de uma época em que

os ingleses parecem estar começando a exagerar sobre quantos antilhanos estão chegando no país: era uma época em que pra qualquer lado que você se virasse um de cada dez era capaz de ser um negrão. ${ }^{4} \mathrm{Na}$ real, os garotos estão por toda Londres, não tem um lugar que não se encontrem, e tem uma grande discussão rolando no Parlamento agora sobre a 
situação, embora a velha Inglaterra seja diplomática demais pra reduzir a quantidade dos garotos ou fazer algo drástico como impedir que eles venham para a Pátria Mãe. Mas tem grandes manchetes nos jornais cada dia, e o que quer que os jornais e a rádio digam neste país, esta é a Bíblia do povo. Como uma vez quando os jornais disseram que os antilhanos pensavam que as ruas de Londres eram calçadas com ouro e um cara foi falar com o pessoal do imposto de renda pra descobrir uma coisa e a primeira coisa que o funcionário diz é, 'Vocês pensam que as ruas de Londres são calçadas com ouro?' O jornal e a rádio governam este país (p. 8).

Além de refletir a crescente insatisfação com a política de "portas abertas $^{\prime \prime}{ }^{5}$, ressalta-se, nesta descrição, o fenômeno da migração ao reverso (agora são os coloniais que se dirigem à metrópole, e não o movimento inverso) através da inversão a lenda do El Dorado, que agora passaria a ser situado no Velho Mundo, como sugere a expressão recorrente "vocês pensam que as ruas de Londres são calçadas de ouro". Originado a observação dos costumes dos Muisca, cujo corpo era recoberto de ouro durante cerimônias rituais, o termo El Dorado (o índio dourado), passou, por extensão, a designar o território mítico em que esse minério era achado em abundância, originado varias expedições européias a terras americanas. Embora a alusão às ruas de ouro obviamente é usada para referir-se a Londres como um lugar onde se pode enriquecer rapidamente, a insistência com que a frase é repetida e a irritação evidente com que os ingleses a pronunciam a tornam instrumental em denunciar o preconceito e o mal estar que aqueles sentem com a entrada dos negros em massa em seu país.

Dividida entre a população branca e a negra, e obedecendo ainda a divisões de classe em cada grupo, Londres se apresenta aos olhos do migrante rigidamente compartimentada e estratificada:

Londres é um lugar assim. Divide-se em pequenos mundos e você fica no lugar a que você pertence e não sabe nada do 
que está acontecendo nos outros lugares a não ser que leia nos jornais. Os ricos que moram em Belgravia e Knightsbrige e na parte de cima de Hampstead e em outros lugares metidos a sebo nunca acreditariam o que é um lugar aterrador como Harrow Road ou Notting Hill. Os que têm carro, que vão ao teatro ou ao balé no West End, que assistem premières com a família real, não sabem nada sobre correr pra conseguir comprar couve de Bruxelas e um quarto de quilo de batata, ou entrar na fila pra comprar peixe e bata frita debaixo da cerração. (Selvon, p. 58)

Em The Lonely Londoners reservam-se aos negros subúrbios então decadentes como as adjacências de Bayswater Road e de Charing Cross Road, Notting Hill, Ladbroke Grove, Clapham e Brixton, com sua grande concentração de jamaicanos. Contrastando com a Londres sombria que lhes serve de lar ou de local de emprego, os negros escolhem como cenário para encontros entre amigos e flertes os mesmos locais que atraem as simpatias da população branca, como Piccadilly Circus, Oxford Street, Marble Arch e o Hyde Park.

O preconceito latente ou explícito na geografia londrina é também explorado por Phillips em The Final Passage. Não escapam a Leila as diferenças entre os espaços ocupados pela população branca e aqueles reservados aos migrantes de cor. Nas repetidas idas ao hospital em que a mãe definha observa que em algumas áreas há muitos negros e poucos em outras, e que a sujeira, poluição e pobreza aumentam à medida em que o ônibus se aproxima dos bairros habitados pela população de cor. Assim, define o ser negro em Londres a partir de indicativos de carência ("não tinham carros grandes, nem vestiam ternos ou carregavam pastas, e tinham um olhar triste e gelado") que têm como parâmetro comparativo implícito a qualidade de vida da população londrina branca. A procura de uma residência faz com que Leila se defronte com o preconceito racial mais de perto, seja através das variadas desculpas dadas pelos proprietários cujos imóveis subitamente já não estão disponíveis, ou através de placas que 
abertamente declaram "Não se aceitam pretos" ou "Não se aceitam pessoas de cor".

Não admira, assim, que Londres pareça aos antilhanos um lugar extremamente solitário. Como definida por Moses Aloetta, "é uma cidade solitária miserável, e se não fosse a gente se reunir de vez em quando e conversar sobre as coisas lá em casa, a gente ia sofrer o diabo" (Selvon, p. 114). Apesar do fato de que o isolamento e abandono experimentado por esse segmento populacional é minorado através da convivência nas comunidades diaspóricas, mesmo em seu interior percebe-se diferenciação. Recordando a pensão em que morara mal chegado à Inglaterra, Moses recorda que havia "os caras de fé, que estavam realmente estudando uma profissão, mas havia também os que só estavam fazendo tempo e esperando para ver o que o amanha traria" (p. 31). Distinguem-se, assim, dois tipos de migrantes: os que vêm à Inglaterra com objetivo definido e aqueles que são movidos apenas pela esperança de dias melhores. Esse raciocínio faz-se bem explicito na categorização feita por Galahad ao comentar o papel da imprensa na disseminação do preconceito: "'O que eu me refiro,' Galahad diz, 'é a impressão que a imprensa dá aos ingleses, sempre falando sobre os caras vindo pra cá pra trabalhar e criar problema. Quer dizer, tem um monte de outros que vem pra estudar e visitar etc, não tem só os sem eira nem beira como nós' (p. 117).

Outro fator diferenciador dentro da comunidade enfocada no romance é a raça. Embora sejam todos negros, nuanças de cor são assinaladas. Aos olhos de Moses, Bart, que "tem pele clara", "não está nem cá nem lá, embora ele esteja mais cá do que lá" (p. 45). Essa não é, porém, a visão de Bart, que evita a companhia de pessoas de pele escura e, quando visto em público com eles, tenta dar a impressão de não pertencer ao mesmo grupo. Parece a Moses que assume um ar de quem diz: "Eu estou aqui com estes garotos, mas não sou um deles, olhem a cor de minha pele" (p. 47). Para os ingleses, porem, Bart é tão negro quanto qualquer outro, e o pai de sua namorada branca o expulsa de casa porque "não quer nenhuma criança de cabelo encaracolado na família" (p. 49). A adoção de uma escala que privilegia as tonalidades 
mais próximas à branquitude testifica a alienação cultural pela negação da própria cor; por outro lado, o contato com o branco destrói a imagem assimilacionista, fazendo com que se enxerguem na sua negritude.

A adoção dos valores da sociedade branca é descrita por Frantz Fanon como estratégia afiliativa gerada pela sensação de deslocamento. Em contato com a sociedade hegemônica, gera-se uma sensação de inferioridade que tem primariamente raízes econômicas, mas que reflete também a internalizacao da tese da inferioridade negra - a "epidermalização" dessa diferença, no dizer de Fanon (1967, p. 11). Uma vez aceita esta tese, a adoção do estilo daqueles a quem se julga culturalmente superiores torna-se uma forma ingênua de combater a percebida inferioridade:

Vestir roupas européias, quer sejam trapos ou a última moda; usar mobília européia e fórmulas de interação social em uso entre os europeus; adornar a língua nativa com expressões européias; usar frases bombásticas ao falar ou escrever uma língua européia-todos estes contribuem para produzir um sentido de igualdade com o europeu e suas conquistas (Westermann, apud Fanon, p. 25)

Harris, levado a assumir os costumes britânicos a ponto de parecer mais inglês que os próprios ingleses, tipicamente exemplifica esse comportamento assimilativo. O personagem de Selvon

gosta dos costumes ingleses e tal, e fica todo polido e diz obrigado e se levanta no ônibus e no metrô pra dar lugar pras mulheres, queé uma coisa que mesmo os ingleses não fazem. E quando se veste, você pensa que é um inglês indo trabalhar no centro, chapéu e guarda-chuva, e pasta enviada debaixo do braço, com o Times dobrado de forma que o nome apareça, e ele caminhando todo erguido como se fosse a única pessoa viva no mundo. Só tem uma coisa: a cara do Harris é preta (p. 95). 
Contrastando com Bart e sua presumida superioridade baseada na tez menos escura, Harris procura distinguir-se com base no modo de agir. A diferença traçada por ele entre a "gente decente"—seus "convidados ilustres", todos brancos-e os amigos e compatriotas negros que autoriza a freqüentar suas festas é estratégia de sobrevivência, uma vez que faz das festas que organiza sua fonte de renda. Como percebido por Rahim (2005), as duas estratégias que adota para ascender no rigidamente estratificado status quo - a mímica (no sentido usado por Naipaul) e a organização de versões turísticas das festas antilhanas -acabam por torná-lo tanto um mímico como um embaixador da cultura natal, que é a fonte de sua insegurança.

Outra estratégia asssimilativa manifesta-se através de um fascínio incondicional pela capital londrina. Face ao apagamento da originalidade cultural, a elevação do nível primitivo faz-se na proporção em que os padrões culturais da metrópole são adotados (Fanon, 1967, p. 19). Falando de um contexto do Caribe fancófono, o psiquiatra martinicano descreve como a auto-estima do migrante colonial aumenta à medida em que se distancia da terra natal: berço da cultura e da estrutura administrativa herdada pela colônia, a metrópole representa o Tabernáculo. Assim, o esmero com que Galahad se veste e o seu sentimento ao caminhar "como um rei" nas ruas de Londres, ou ainda a atração de Big City pelas grandes cidades são procedimentos compensatórios através dos quais estes personagens procuram contrabalançar a miséria em que vivem e a discriminação de que são alvo.

Ainda quando sutilmente disfarçada pela "velha diplomacia" inglesa, a discriminação se manifesta, também no romance de Selvon, através dos lugares em que os negros são acolhidos. No ambiente de trabalho reservam-se a eles os piores e mais mal pagos serviços, e sua cor é discriminada na ficha de emprego para permitir ao empregador seleção prévia com base na cor. Na política habitacional a rejeição pode assumir tanto a forma de polida mentira sobre a indisponibilidade de vagas como formas mais ostensivas, como a placa "Mantenha Bayswater Branca". Nos lugares públicos, como nos bares, a discriminação varia de um claro convite à retirada a um atendimento gélido. 
Mesmo coloniais fascinados pela metrópole como Galahad têm sua confiança abalada quando compelidos a encontrar o olhar do branco. Seis anos depois de publicado o memorável episódio em que Fanon descreve o encontro de um colonial com o "fato da negritude", 0 personagem de Selvon reencena o encontro com a menina branca. Diferentemente do episódio descrito por Fanon, não há a tríplice renovação do convite por parte da menina, que apenas uma vez diz: "Mamãe, olha aquele negro!" Deixa de existir, consequentemente, o crescente desconforto do negro, intensificado a cada chamamento da menina. Galahad é chamado à prova sob as mais favoráveis condições possíveis: está em um dos locais que mais estimulam sua ligação com a cidade, a estação de metrô de Piccadilly, e é verão, quando o frio e a solidão da cidade grande são esquecidos, e sente-se novamente acolhido em Londres. Ademais, o episódio acontece quando já está bem familiarizado com a cidade. Ainda assim, ao presenciar o medo que desperta na menina, evidentemente não escapa a ele o caráter discriminatório do encontro. Como explica Fanon a propósito do episódio narrado em seu livro, o que causa medo à menina não é a pessoa física que vê a sua frente, mas as histórias, conceitos e preconceitos a partir dos quais constrói o ser a sua frente. Assim, o esquema racial se desintegra ante o esquema histórico-racial, e a imagem que impressiona a criança nãoé a formada pelos sentidos, mas a formada por um esquema epidérmico-racial que se sobrepõe àquela imagem (Fanon, 1967, p. 110-112). Embora Galahad se gabe de certa imunização de emoções por ocasião do episódio, confessa também que há momentos em que o peso acumulado das práticas discriminatórias pesa sobre ele. Tal como Moses, que percebe a irracionalidade da sobredeterminação da personalidade do negro com base no esquema epidérmico ${ }^{7}$, Galahad percebe a discriminação como tendo origem basicamente na cor. Num indicativo de seu deslocamento e alienação, concebe a si e a sua cor como duas entidades separadas. Em um dos mais patéticos momentos da obra, lamenta que não possa ser branco e atribui à cor toda a causa de sua miséria, embora a conceba como associada a características usualmente associadas à cor branca, como pureza e inocência: 
Cor, você está causando tudo isso, você sabe. Por que você não pode ser azul, ou vermelha ou verde, se você não pode ser branca? Você sabe que é você que causa toda a dor do mundo. Não sou eu, é você, você sabe! Eu não faço nada para encolerizar as pessoas, é você! Olhe para você, tão preta e inocente, e agora causando dor em todo o mundo!(p. 72)

Uma terceira estratégia afiliativa é a valorização da mulher branca. De forma geral mulheres, especialmente em situação econômica superior a dos migrantes, são vistas como indicador do sucesso (por limitado que possa ser), e muito especialmente quando se trata de mulheres brancas. Daniel faz questão de levá-las a concertos porque se realiza ao pensar que jovens negros também podem levá-las a esses lugares. O orgulho de Galahad depois de ter relações com a primeira mulher branca, Daisy, e a atitude de Tolroy, que despreza a jamaicana bonita que Agnes lhe apresenta são duas expressões do desejo inconsciente de ser branco. Incorporando a cultura e padrões de beleza de sua raça, a mulher branca funciona como símbolo-acariciá-la equivale a acariciar e apropriar-se da civilização branca e de sua dignidade (Fanon, 1967, p. 63). Por outro lado, mulheres brancas de alta posição procuram os migrantes antilhanos com base no conhecimento estereotípico de seu primitivismo e potência. Mais uma vez acentua-se o papel da mídia como formadora de opinião. As mulheres que procuram o homem negro não o vêem como pessoal, mas como instrumental em lhes provocar prazer, fazendo-as experimentar sensações imaginadas a partir de filmes e romances. Como Moses pondera,

não adianta assumir um sotaque britânico (...) ou falar que está estudando medicina em Oxford ou tentar ser educado e civilizado elas não querem esse tipo de coisa elas querem que você viva como nos filmes e histórias que elas escutam sobre os negros primitivos morando nas selvas é por isso que você vê tantos caras na cidade com o cabelo tão alto como se não cortassem a cabeleira por anos e com uma cicatriz na 
face e uma expressão feroz andando com essas gurias da alta quanto mais grosso você for mais elas gostam de você (...) Moses perguntou para uma gata uma noite e ela falou pra ele como os garotos negros são tão maravilhosos e como causam uns arrepios que ninguém acredita (p. 92).

O conhecimento estereotípico que transforma o negro em objeto de desejo é enfocado em The Final Passage a partir da perspectiva de Leila. A atração da mulher branca pelo negro representa ameaça para ela, ainda quando aquela mantenha relacionamento ocasional com seu marido, explorando o corpo de Michael "como se fosse um condado da Inglaterra nunca dantes explorado" (p. 194).

A mulher branca representa um enigma para Leila desde sua infância em St. Patrick. Como Millie, pensa que aquela se comporta de maneira estranha, o que é exemplificado através da descrição do ritual do bronzeamento, que parece a Leila a manifestação de um ilógico e impossível desejo de ser negra. Já adulta, na Inglaterra, a imagem da mulher que a enganara quando menina, levando-a a acreditar que lhe ofertava um doce quando na verdade lhe estendia a mão vazia conflitua com a imagem de Mary, cuja amizade não pode negar.

Bastam a Leila cinco meses para que a tendência integrativa manifestada por ela ao emigrar se desfaça. Uma vez que sua decisão é em grande parte motivada pelo desejo de que o Velho Mundo lhe oportunize um recomeço, sob novas bases, das relações com a mãe e o marido, a morte daquela e o fim do casamento desfazem as bases dessa motivação. A nova gravidez e o desemprego aumentam-lhe a sensação de deslocamento. Embora tente, é-lhe difícil imaginar quando poderá ser "feliz na Inglaterra com duas crianças, e nenhum pai, e pouco dinheiro" (p. 194). Seu senso de deslocamento é dimensionado pelas repetidas visitas que faz ao cemitério, numa tentativa inútil de forjar elos familiares já agora impossíveis de virem a se tornar reais. Seu isolamento e alteridade são ainda dramatizados na cena em que o filho lhe pede que confirme a identidade de Papai Noel, quando lhe aflora à mente a pergunta "Por que Papai Noel não é de cor?" (p. 202-03). A 
indagação, que se repete exaustivamente, sugere não apenas a valoração da identidade branca como a situação desvalida do negro, não identificado com aquele que traz presentes e recompensa aos reconhecidamente bem comportados e bons.

Ao início do romance, a tendência integrativa de Leila é simbolizada por sua escolha de levar o mínimo possível de St Patrick na única mala que carrega para a Inglaterra. Ao final da obra, a decisão de queimar todas as posses adquiridas em solo inglês expressa sua rejeição ao país que não pode legitimamente chamar de lar. Ainda que o preço de abandoná-lo seja a separação definitiva de Michael e a certeza da previsibilidade da vida rotineira em sua terra natal, decide voltar para sua pequena ilha, onde sabe que tem pelo menos dois amigos, muito embora permaneça em aberto, ao fim do romance, se o retorno efetivamente terá lugar. A expressão de não pertencimento expressa pela mãe de Leila quando da primeira visita da filha ao hospital - "Leila, filha, Londres não é meu lar" (p. 124) - poderia ser tomada para definir o sentimento da protagonista com relação à capital da metrópole nesse momento.

Mesmo quando percebida pelo migrante como o não-lar, a Inglaterra deve ser construída como o lugar de habitação, por temporário e frio que possa ser. Em The Lonely Londoners as repetidas advertências "Londres não é como Port of Spain" (p. 21), "aqui não é a Jamaica, e Londres não é como Kingstown" (p. 58) ou ainda "aqui não é como lá em casa, que a gente tem amigos em toda a parte" (p. 114) têm a função de instruir a população antilhana quanto a assuntos que vão da natureza dos relacionamentos sociais-superficiais e impessoais quando comparados com o companheirismo e apoio mútuo típicos das sociedades de origem-à discussão dos direitos da mulher. Assim, mais do que o estabelecimento de uma diferença, trata-se de ajudar aqueles que oscilam entre a cultura antilhana e a inglesa a construir padrões de conduta compatíveis com o novo espaço cultural em que se movem. A natureza do local ocupado por essa população é exemplarmente simbolizada no romance de Selvon pela mercearia freqüentada por Tanty, cujo proprietário é compelido a aceitar que suas 
clientes adotem sistema de crédito semelhante ao adotado nos países de origem, ou ainda pela alusão à festa de Harris como Saltfish Hall em Londres $^{8}$ (p. 99).

Em The Final Passage, a habilidade de construir esse espaço híbrido -o "terceiro espaço" de Bhabha -é em grande parte responsável pelo sucesso dos protagonistas. Motivado a evitar o fracasso, Michael preserva sua tendência afiliativa, e se esforça para construir seu espaço, movendo-se entre a comunidade diaspórica antilhana e a inglesa. Já Leila, para quem os atrativos da Inglaterra haviam desaparecido, fecha a mente para o país em que vive. Tendo já em pensamento deixado a Inglaterra para trás, concentra-se no passado, buscando fatos que atestem a superioridade de sua ilha em relação à Inglaterra, como o peixe deixado na soleira das portas ao alcance dos cachorros. Projeta também o pensamento para o futuro, quando voltará a habitar lá, relegando o presente a ponte entre esses dois momentos.

Como reavaliada por Selvon e Phillips, a chegada da geração Windrush à Europa expõe a ficção da pátria mãe; há, concomitantemente, o desnudamento da ilusão do conhecimento presumido do país pelos coloniais, e o questionamento do seu real status em solo britânico. Este processo se faz particularmente intenso pela situação temporal que serve de cenário a ambos os romances, quando o impacto causado pela chegada de migrantes em massa torna visível aos olhos dos ingleses uma população de que até então tinham conhecimento de segunda mão. O encontro provoca o acirramento dos preconceitos contra eles, e origina medidas de restrição/contenção. No que tange aos cidadãos vindos da colônia, observa-se que a adoção de estratégias afiliativas favorece a construção da nova identidade cultual na Inglaterra, facilitando o processo de transição da cultura de origem para a construção de seu novo espaço em solo inglês. Nada, porém, tem importância mais decisiva do que o apoio prestado pelas comunidades diaspóricas que, assistindo o migrante desde o processo da chegada, provêem o apoio logístico e humano de que necessitam para construir seu espaço na nova realidade com que se defrontam. 


\section{Notas}

1. Face à inexistência de tradução portuguesa dos romances analisados, esta e as demais citações dos originais em inglês estão em tradução da autora.

2. Os migrantes referem-se à história da Inglaterra escrita por Churchill como Historia do Povo Inglês, quando na verdade o título é História dos Povos de Língua Inglesa. A famosa História Eclesiástica do Povo Inglês, escrita por Bede, que certamente deveria ser do conhecimento dessa população devido aos moldes britânicos adotados pelo sistema educacional na colônia, pode ter gerado a confusão. Em sua ânsia afiliativa, ao apagar do nome do livro a expressão "povos de língua inglesa", omitem a referencia que os incluiria, como coloniais, na história escrita por Churchill. Iniciando com a invasão romana em 55 BC, a obra cobre até o início a Primeira Guerra Mundial (1914); a crença numa "relação especial" da GrãBretanha com os povos pertencentes à Commonwealth e o contraste com o povo americano, que cedo se torna independente, reflete-se numa correspondente divisão dual dos povos de língua inglesa no livro.

3. O discurso "We shall fight on the beaches", proferido a 4 de junho de 1940, ilustra este ponto, como evidencia a famosa frase: "(...) nunca nos renderemos, mesmo se (...) esta ilha (...) fosse subjugada (..) então nosso império além mar, armado e guardado pela Marinha Britânica, levaria avante esta luta até que, no tempo determinado por Deus, o Novo Mundo, com todo o seu poder e força, marchará avante para socorrer e libertar o Velho Mundo'.

4. A palavra traduzida por "negrão" é spade no original. Em seu sentido primário, refere-se a espadas, do naipe de cartas, cuja aparência preta e pontuda lembra a aparência da cabeça dos migrantes negros. O termo, naturalmente, era considerado ofensivo.

5. A lei da Nacionalidade Britânica de 1948 confirmava o direito de entrada em solo inglês dos cidadãos das colônias, que eram considerados cidadãos ingleses.

6. Refiro-me ao encontro do negro com a menina branca, como narrado em Pele Preta, Máscaras Brancas, cuja primeira edição data de 1952 - seis anos antes, portanto, da primeira edição de The Lonely Londoners, em 1956.

7. Instruindo o recém-chegado Galahad sobre a vida em Londres, Moses explica a ele que os ingleses não gostam da população de cor, dizendo: “(...) eles não gostam de gente preta, e não me pergunte por que, essa é uma questão que gente com o cérebro bem maior do que o meu está tentando resolver há muito tempo" (p. 23). 
8. Como explicado no próprio romance, Saltfish é o nome de um lugar em uma das pequenas ilhas do Caribe em que havia uma placa na qual estava escrito "Lave Seus Pés e Entre". Ao lado da porta havia dois baldes com água, com o qual os trabalhadores que vinham do campo lavavam seus pés antes de entrar no salão. Assim, a referência a Saltfish Hall sugere ajuntamento inclusivo, que abriga a quem quer que dele queira participar.

Incorporando a cultura e padrões de beleza de sua raça, a mulher branca funciona como símbolo-acariciá-la eqüivale a acariciar e apropriar-se da civilização branca e de sua dignidade (FANON, 1967, p. 63).

\section{Referências}

BHABHA, Homi. O Local da Cultura. Belo Horizonte: UFMG, 1998.

CHURCHILL, W. We shall fight on the beaches. In: Selected Speeches. Washington, DC: The Churchill Center, n. d. Disponível em < http:/ / www.winstonchurhill.org/ i4a/index.cfm?pageid=393>. Acesso em: 28 out. 2007.

FANON, Frantz. Black Skin, White Masks. New York: Grove Press, 1967.

HALL, Stuart. Cultural Identity and Diaspora. In: MONGIA, Padmini (ed.) Contemporary Postcolonial Theory: A Reader. London: Arnold Hodder, 1990. p. $110-21$.

PHILLIPS, Caryl. The Final Passage. New York: Vintage, 1985.

RAHIM, Jennifer. (Not) Knowing the difference: Calypso overseas and the sound of belonging in selected narratives of migration. Anthurium v. 3, n. 2, fall 2005. Disponível em <http://scholar.livrary.miami.edu/anthurium/volume_3/ isuuse_2/rahim-notknowing.htm>. Acessado em: 15 out. 2007.

RUTHERFORD, Jonathan. O Terceiro Espaço: uma entrevista com Homi Bhabha. Revista do Patrimônio Histórico e Artístico Nacional. Rio de Janeiro. v. 24, p. 3541, 1996.

SELVON, Sam. The Lonely Londoners. Toronto: Tsar, 1991. 